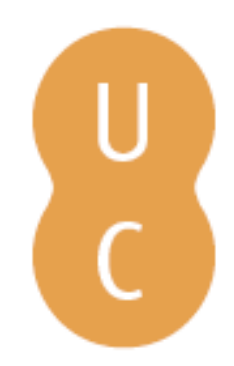

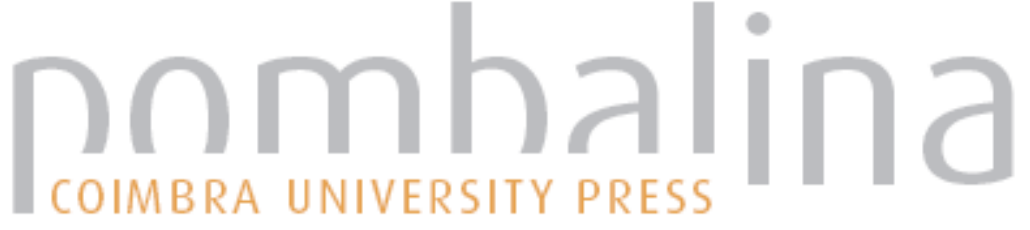

\section{Ethanol consumption \& road traffic accidents: an overview between 1990 and 2007 in the centre of Portugal}

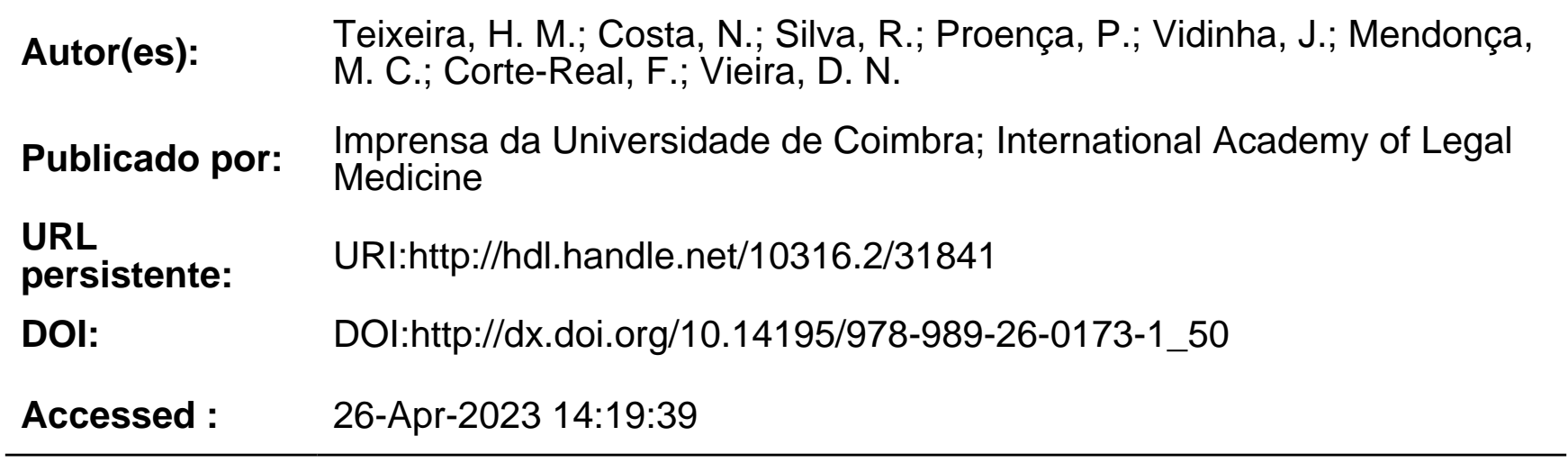

A navegação consulta e descarregamento dos títulos inseridos nas Bibliotecas Digitais UC Digitalis, UC Pombalina e UC Impactum, pressupõem a aceitação plena e sem reservas dos Termos e Condições de Uso destas Bibliotecas Digitais, disponíveis em https://digitalis.uc.pt/pt-pt/termos.

Conforme exposto nos referidos Termos e Condições de Uso, o descarregamento de títulos de acesso restrito requer uma licença válida de autorização devendo o utilizador aceder ao(s) documento(s) a partir de um endereço de IP da instituição detentora da supramencionada licença.

Ao utilizador é apenas permitido o descarregamento para uso pessoal, pelo que o emprego do(s) título(s) descarregado(s) para outro fim, designadamente comercial, carece de autorização do respetivo autor ou editor da obra.

Na medida em que todas as obras da UC Digitalis se encontram protegidas pelo Código do Direito de Autor e Direitos Conexos e demais legislação aplicável, toda a cópia, parcial ou total, deste documento, nos casos em que é legalmente admitida, deverá conter ou fazer-se acompanhar por este aviso.

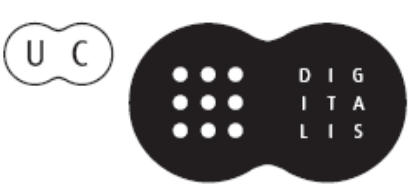




\section{Duarte Nuno Vieira Anthony Busuttil \\ Denis Cusack • Philip Beth}
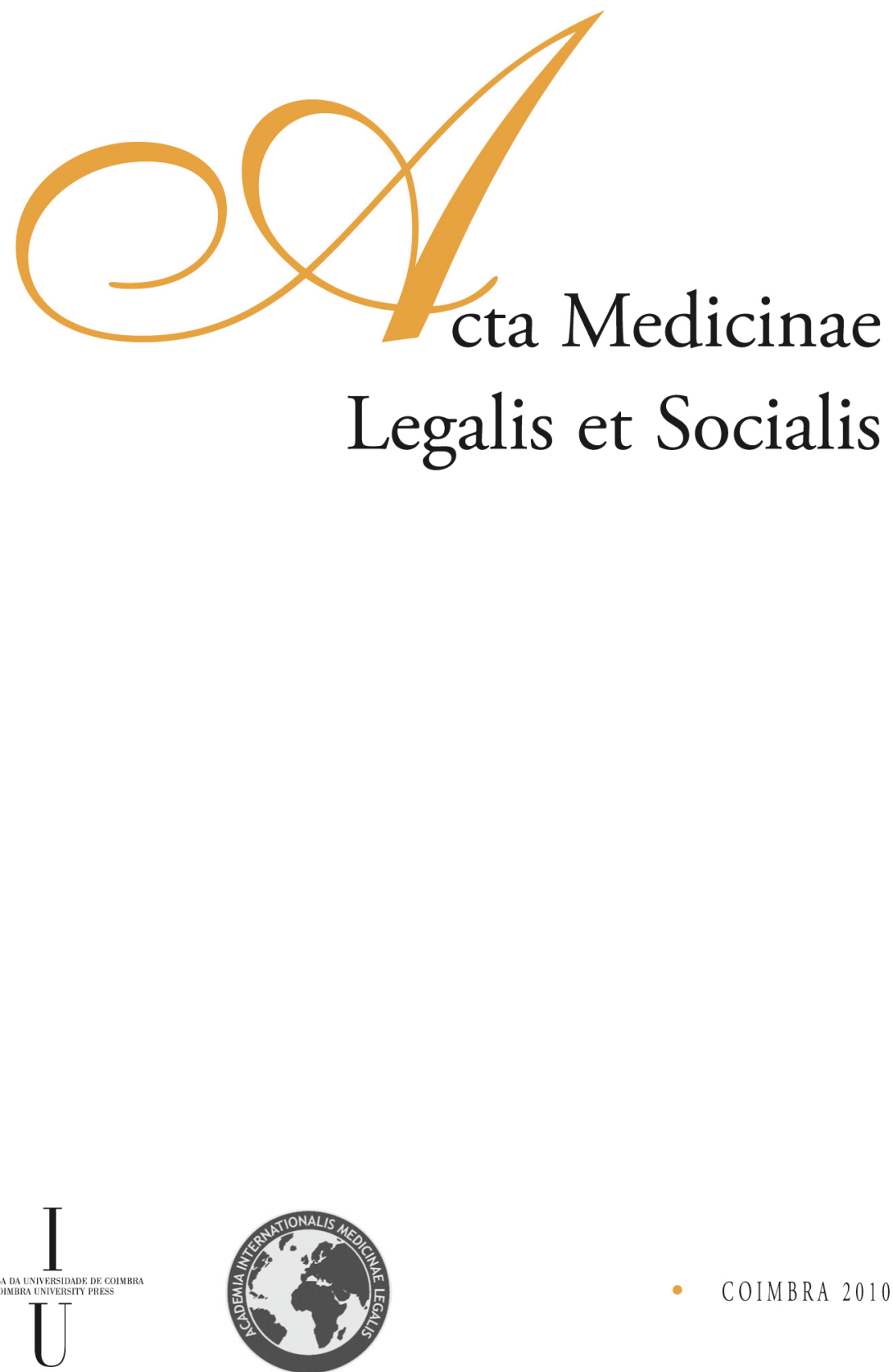
H. M. Teixeira ${ }^{1,4}$, N. Costa ${ }^{2}$, R. Silva ${ }^{3}$, P. Proença ${ }^{2}, J$. Vidinha ${ }^{2}$, M. C. Mendonça ${ }^{2,4}$, F. Corte-Real ${ }^{2,4}$, D. N. Vieira ${ }^{2,4}$

${ }^{1}$ North Branch of the National Institute of Legal Medicine, Oporto, Portugal

${ }^{2}$ Centre Branch of the National Institute of Legal Medicine, Coimbra, Portugal

${ }^{3}$ Figueira da Foz Legal Medicine Office, National Institute of Legal Medicine, Portugal

${ }^{4}$ Faculty of Medicine, University of Coimbra, Portugal

\title{
ETHANOL CONSUMPTION \& ROAD TRAFFIC ACCIDENTS: AN OVERVIEW BETWEEN 1990 AND 2007 IN THE CENTRE OF PORTUGAL
}

\begin{abstract}
Ethanol is the most frequently detected drug in deaths from all causes, particularly traffic and labour accidents. The aim of this study was to assess the presence of alcohol among drivers involved in fatal road traffic accidents between January 1990 and December 2007, by presenting the requests and ethanol results of the road traffic accidents autopsies, from the Pathology Service of the Centre Branch of the National Institute of Legal Medicine and from a Legal Medicine Office. In the Forensic Pathology Service and in the Office a total of 9409 and 1219 autopsies were performed, respectively, 3095 and 336 on road traffic accidents victims. Ethanol analysis was requested only in $54.5 \%$ and $75 \%$ of the road traffic accident cases, with $31 \%$ and $47 \%$ positive results, respectively. The major percentage involved concentrations over the maximum limit legally allowed $(1.2 \mathrm{~g} / \mathrm{L})$, being this undoubtedly present in males with ages between 21 and 30 years-old. Research has identified alcohol as a significant factor related to traffic accidents and this has led to specific legislation and methods of enforcement to prohibit this form of impaired driving.
\end{abstract}

Keywords: Ethanol; road traffic accidents.

\section{Introduction}

It has been estimated that more than 2 million people are killed each year in road traffic accident worldwide. Within the European Union, traffic accidents result yearly in 50000 fatalities and 1.5 million injuries. Ethanol plays an increasing role in accidents, as accident severity increases [1]. Research has shown that alcohol impairs driving skills and increases crash risk. In Portugal, the legislation related to road traffic and safety is laid down in the Road Traffic Code and specific additional legislation. It states that it is forbidden to drive a vehicle under the influence of a substance of which the driver ought to know that it affects the driving proficiency. For alcohol, there are three legal limits, $0.5 \mathrm{~g} / \mathrm{L}, 0.8 \mathrm{~g} / \mathrm{L}$ and $1.2 \mathrm{~g} / \mathrm{L}$, with different penalties.

This paper presents a retrospective analysis of the toxicological investigation on biological samples from fatally injured drivers, between January 1990 and December 2007, to determine the role, if any, of ethanol amongst fatal road traffic accidents. 


\section{Material and Methods}

This study has been carried out by the National Institute of Legal Medicine of Portugal. The target population consisted of drivers killed in road accidents. The data available in each case was: year, sex, age and alcohol concentrations.

The authors present the requests and consequent ethanol results of the road traffic accidents autopsies performed from 1990 and 2007 in the Pathology Service of the Centre Branch of the National Institute of Legal Medicine (NILM) and performed from April 2001 (open date of the office) and 2007 in the Legal Medicine Office of Figueira da Foz (LMO). All ethanol analyses were performed in the Forensic Toxicology Laboratory of the Centre Branch of the NILM.

Several variables were studied and all the pertinent data was registered, separated and statistically treated with the SPSS program (Statistical Package will be Social Sciences).

\section{Results and Discussion}

Driver impairment is a significant factor that has been associated with accident risk. Research has identified alcohol as a significant factor related to traffic accidents and this has led to specific legislation and methods of enforcement to prohibit this form of impaired driving.

As mentioned above, the main objective of our work was the analysis of all road traffic accident cases from autopsies performed in the Forensic Pathology Service of the Centre Branch of the National Institute of Legal Medicine (NILM) between 1990 and 2007 and performed from April 2001 and 2007 in the Legal Medicine Office of Figueira da Foz (LMO), in order to know the prevalence of alcohol in this cause of death.

It is important to be aware that no related study has been published in Portugal and thus, no comparison with the results now achieved is possible. Consequently, the results will be discussed taking into account our legal medicine system and reality.

Throughout the years, we observed, in the Delegation and in the LMO, a decrease in the road traffic fatal accidents. In fact, in the Delegation, the year 2006 registered a less number of cases, with only 77 cases $(2.5 \%)$, followed by $3 \%$, in 2007 . In the LMO, this less percentage was achieved in 2007, with only 23 cases, corresponding to $6.8 \%$.

Indeed, it is important to remember that the road traffic safety European plan has as main objective the reduction on the number of accident victims in the European Union, in 2010, being "driving under the influence of alcohol and drugs" a phenomenon described as one of the most disturbing accident risk factor.

Thus, it has been recommended to all the UE countries some guidelines to fight against this problem, such as the application of a harmonized procedure to detect illicit drugs in all drivers involved in fatal accidents, the use of onsite screening devices, an adequate training of the police, etc. All these initiatives, added to the fact that, during the years, new hospitals have been build with better and increased assistance, lead to a major surviving percentage and the consequent decrease in deaths due to road traffic accidents. 
In the Forensic Pathology Service a total of 9409 autopsies were performed between 1990 and 2007, 3095 on road traffic accidents victims, 78\% in male victims (Fig.1). In the Legal Medicine Office, from April 2001 to 2007, 1219 autopsies were performed, 336 to car accident victims, $82 \%$ men (Fig.6).

Although Portuguese culture have suffered deep changing during the years, observing a huge number of women with active and professional activities and with driving licence, in fact, there will always be a major number of male drivers, as also stated by other authors [2,3].

Moreover, despite the jargon assume that a female driving will result in constant danger, we believe that the data obtained can now be justified by a driving behaviour sometimes more aggressive and competitive by men [4], especially in individuals between 21 and 30 years (higher range detected, about $25 \%$ in road accidents studied), as described by Williams and Shabanova (2003), resulting in a less cautious behavior and consequent increased number of fatal accidents $[4,5]$.

In the Forensic Pathology Service, ethanol analysis was requested in only 54.5\% of the road traffic accident cases, with $31 \%$ positive results (Fig. 2) and in the Legal Medicine Office from all the car accident files analyzed, 75\% included ethanol analysis request, with $47 \%$ positive results (Fig. 7 ).

In fact, with regard to the years in which this determination was not required, there was a clear predominance from 1990 to 1992, 2001 and 2004 (in the Centre Branch). We can possibly speculate that this lack of alcohol requests on drivers victims of road accidents in 1990 and 1992 was mainly due to a lack of specific legislation, obliging this determination, existent in our country only since 1998, not only through the highway code, but by separate legislation, Law 24/98, 30 ${ }^{\text {th }}$ of October, now repealed by the Law $18 / 2007,17^{\text {th }}$ of May.

The other cases with no alcohol analysis correspond to drivers or pedestrians with hospitalization and subsequent survival over 24 hours and, according to the rules implemented in the Forensic Pathology Services of the NILM, based on scientific evidence, is not required for blood alcohol determination.

On the other hand, it can also include all the cases where there were certain conditions, including thoraco-abdominal trauma or other injuries that led to the absence of biological samples, including blood, turning out impossible any determination. Finally, all the cases suspected of a possible postmortem synthesis of ethanol, such as signs of putrefaction were entirely excluded on the assessment of alcohol, since the results could be unreliable, especially in road accidents cases where the establishment of a state of influence or determination of a legal penalty is the main objective.

Of the positive cases analyzed, we observed that the majority of cases were above $1.2 \mathrm{~g} / \mathrm{L}$, with $51.4 \%$ (283 cases) for the Centre Branch (Fig.3), and 60.2\% (73 cases) for the LMO (Fig. 8). Note that this concentration corresponds to the maximum legal limit permitted by law, while an offense punishable by law. Analyzing the cases in this $\mathrm{BAC}(\mathrm{BAC} \geq 1.2 \mathrm{~g} / \mathrm{L})$, we concluded that there has been a regular consumption through each year, with a predominance of the month of August, in the Branch, and the month of September, in the LMO, possible months conducive to consumption, influenced by natural factors such as temperature, or social factors such as celebrations, holiday periods, highlighting again the sex male with about $95 \%$ of the cases, from 21 to 30 years-old, with about $25 \%$ of the cases (Figs. 4, 5, 9, 10). 
Moreover, we performed the same analysis regarding the distribution of the positive cases by driver, passengers and pedestrians, and concluded that drivers were those with a higher number of positive cases for ethanol, with $51.5 \%$ of the cases in the Branch and $56.9 \%$ of the cases in the LMO.

In the absence of a total or absolute justification for these high values, we can only conclude that these extraordinarily high concentrations have been increasing over the years. It has been discussed in our country, not only the high alcohol consumption as a result of the culture as well as due to the fact that we are strong producers of alcoholic beverages, but the scenario effectively existent of a chronic use of this toxicological substance and consequent high concentrations achieved among drivers. In fact, the NILM is involved in an working group organized by the Institute for Drugs and Drug Addiction which aims to establish standards and strategies to reduce risks associated with alcohol, this plan set for 2009 to 2012 .

\section{Conclusion}

The higher percentage of the analysed cases were violent deaths, with $76.8 \%$ of the cases in the Centre Branch and $66.7 \%$ in the LMO, being the road traffic accidents present in $35,8 \%$ and $31,8 \%$ of these deaths, in the Centre Branch and LMO, respectively.

However, there has been a decrease in the number of deaths from road accidents over the years due to the strong strategy to reduce road accidents and development of health systems.

The vast majority of fatal road accidents occur in males, with about $80 \%$ of the cases, drivers aged from 20 to 40 years, and the car is the vehicle of choice, followed by the motorcycle, with approximately $45 \%$ and $40 \%$, respectively.

From the casuistic study performed it is possible to observe that there is a very high percentage of non required ethanol analysis in car accident fatal victims. However, over the years and consequent law implementation, the number of samples submitted for toxicological analysis (ethanol) from car accident autopsies increased

As also discussed by other authors [2], driving under the influence of alcohol is a persistent problem in our country. The problem of drinking and driving is of special relevance in Portugal. This is due, not only to the fact that alcohol consumption is frequent in our country (and, therefore, driving under the influence of alcohol), but also because of an alcohol-related culture; society is very permissive towards its consumption and tolerant towards alcohol-related problems.

Although comparison with data from other countries should be carefully conducted, the figures observed in our study were among the highest. In the UK [3], data accumulated from 1990 to 1994 revealed that in $45.5 \%$ of deaths alcohol was detected, and that this exceeded $0.8 \mathrm{~g} / 1$ in $20.25 \%$ of the victims. Alcohol has been frequently been detected in Italy (49.0\%) [4], in France $(45.7 \%>0.7 \% \mathrm{~g} / \mathrm{l})$ [5] and in Belgium (28\% over $0.49 \mathrm{~g} / \mathrm{l}$ ) [6], whilst figures for the Nordic countries (Sweden: $27 \%$ [7] and 20.3\% [8], Norway: $28.3 \%$ [9]) are considerably lower, perhaps as a result of the fact that in these countries there exists a very strict policy with regard to drinking and driving. 
Furthermore, Portugal is still one of the European Union countries showing highest figures for road accidents. Consequently, psychoactive drugs and driving are a matter of great interest for developing health policies.

\section{References}

Belgium Toxicology and Trauma Study Research Group, Belgium Toxicology and Trauma Study, Ministry for Transport and Infrastructure and the Ministry for Public Health, Brussels (1996).

CHANDRA S.; REDDY C. (2008). A five-year retrospective statistical analysis of maxillofacial injuries in patients admitted and treated at two hospitals of Mysore city. Indian J. Dent Res, 19(4).

DEVEAUX M. Enquête alcohol, médicaments psychotropes et opiates chez les conducteurs et piétons impliqués dans les accidents mortels de la circulation. Observatoire Régional de Sécurité Routière, Lille, 1995.

DRUMMER, O.H., JIM GEROSTAMOULOS, HELEN BATZIRIS, MARK CHU, JOHN CAPLEHORN, MICHAEL D. ROBERTSON AND PHILIP SWANN (2004). The involvement of drugs in drivers of motor vehicles killed in Australian road traffic crashes. Accident Analysis \& Prevention, 36(2):239-48.

FERRARA SD, GIORGETTI R, ZANCANER S. Psychoactive substances and driving: state of the art and methodology. Alcohol and Drugs and Driving, 10: 1-55, 1994.

FILLMORE, K.M. KAYE MIDDLETON FILLMORE, GOLDING J.M., KNIEP S., LEINO E.V., SHOEMAKER C., AGER C.R., FERRER H.P. (1995). Gender differences for the risk of alcohol-related problems in multiple national contexts. Recent Developments in Alcoholism, Volume 12: Women and Alcoholism, edited by Marc Galanter. Plenum Press, New York, 199512:409-39.

GJERDE H, BEYLICH KM, MORLAND J. Incidence of alcohol and drugs in fatally injured car drivers. Accid Anal Prev, 25:479-483, 1993.

MAYCOCK G. Drinking and driving in Great Britain - a review, Transport Research Laboratory, Berkshire, 1997.

OSTROM M, SJOGREN H, ERIKSON A. Role of alcohol in traffic crashes involving women: passenger car fatalities in northen Sweden. J Stud Alcohol, 56:506-512, 1995.

RIO MC, ALVAREZ FJ. Alcohol among fatally injured drivers in Spain. Forens Sci Int, 104:117-125, 1999.

SMINK BE, RUITER B, KUSTHOF KJ, ZWEIPFENNING PGM. Driving under the influence of alcohol and/or drugs in the Netherlands 1995-1998 in view of the German and Belgium legislation. Forens Sci Int, 120:195-203, 2001.

SJOGREN H, BJORNSTIG U, ERIKSON A, OHMAN U, SOLARZ A. Drug and alcohol use among injured motor vehicle drivers in Sweden: prevalence, driver, crash and injury characteristics. Alcohol Clin Exp Res, 21:968-973, 2003.

WILLIAMS, A. F. E SHABANOVA, V.I. (2003). Responsibility of drivers, by age and gender, for motor-vehicle crash deaths. J. Saf. Research, 34(5):527-31. Insurance Institute for Highway Safety, USA. 


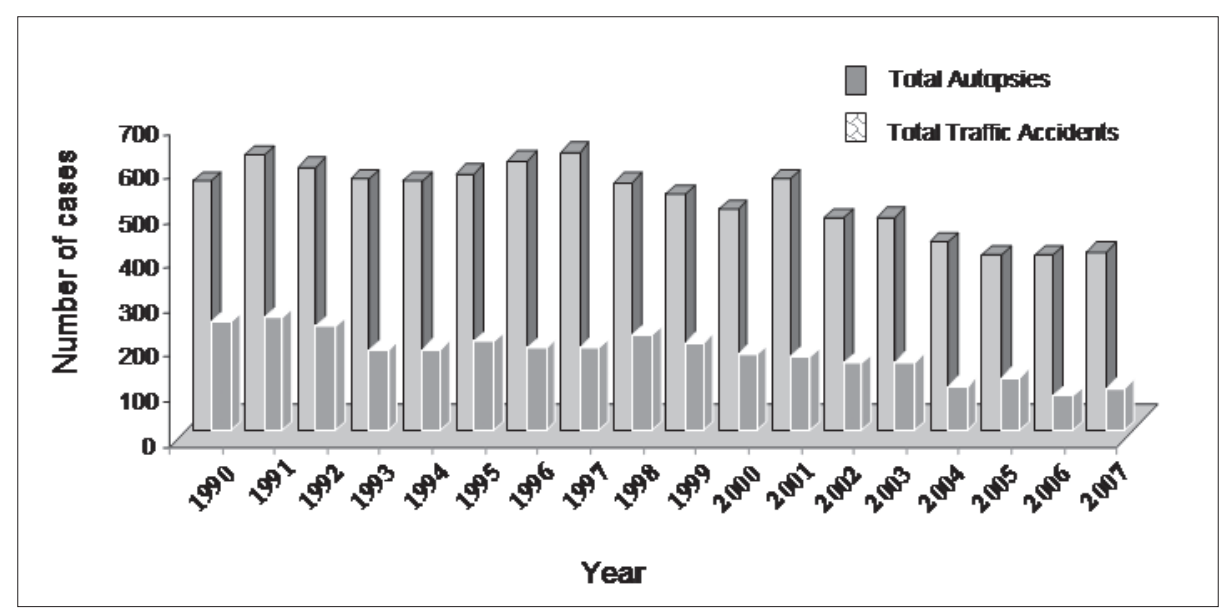

Figure 1 - Number of Traffic Accidents in the autopsies performed in the forensic pathology service between 1990 and 2007.

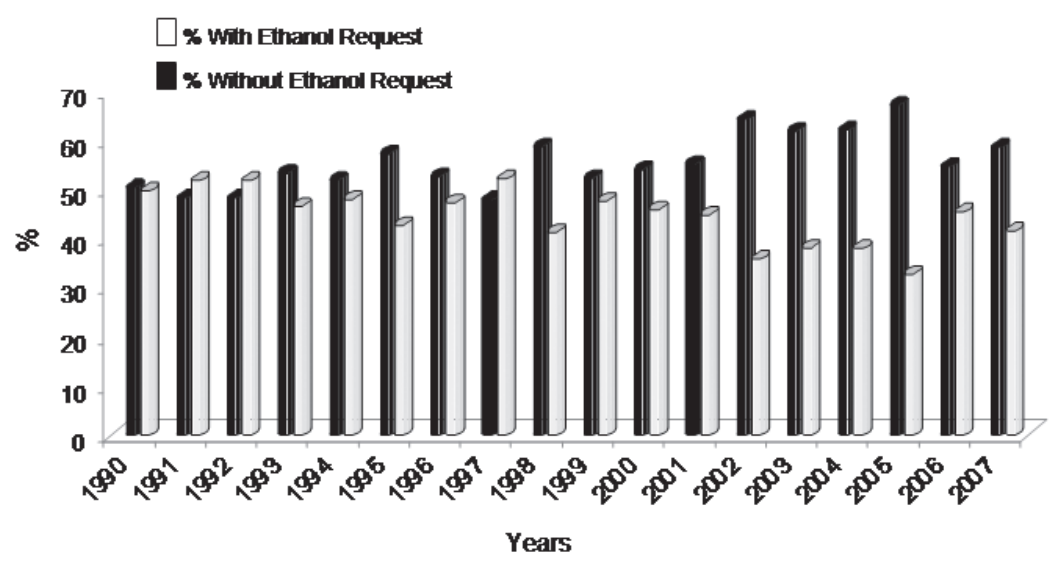

Figure 2 - Number of Traffic Accidents without Ethanol request (in the forensic pathology service).

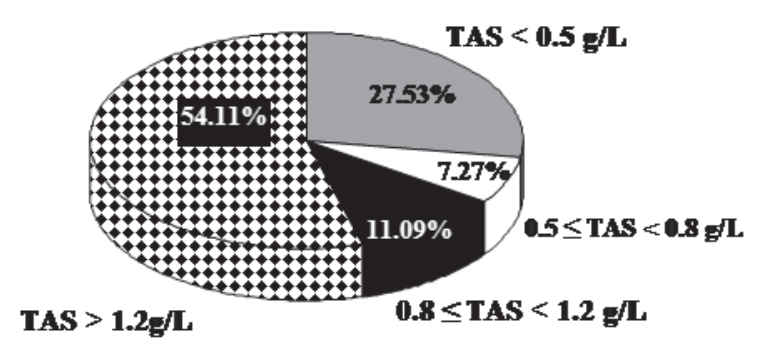

Figure 3 - Positive Ethanol Results distribution in the Centre Branch. 


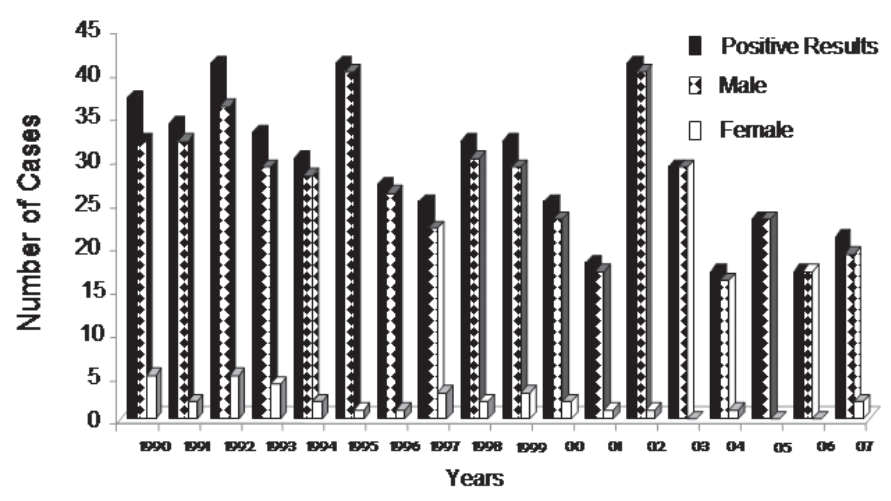

Figure 4 - Positive results distribution per gender/year (in the forensic pathology service).

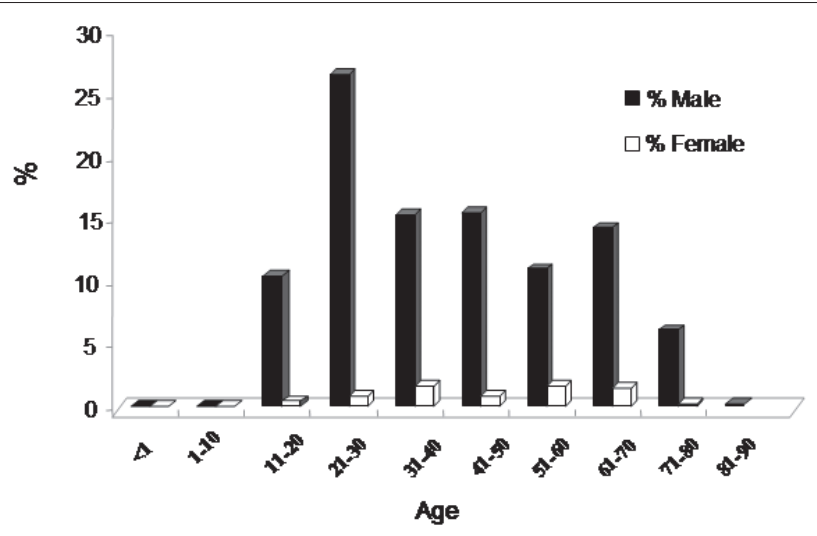

Figure 5 - Positive results distribution per gender/age (in the forensic pathology service).

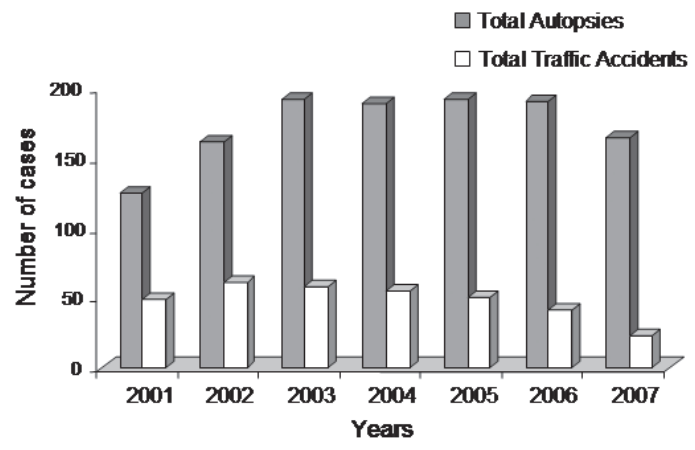

Figure 6 - Number of Traffic Accidents in the autopsies performed in the Legal Medicine Office of Figueira da Foz between 2001 and 2007. 


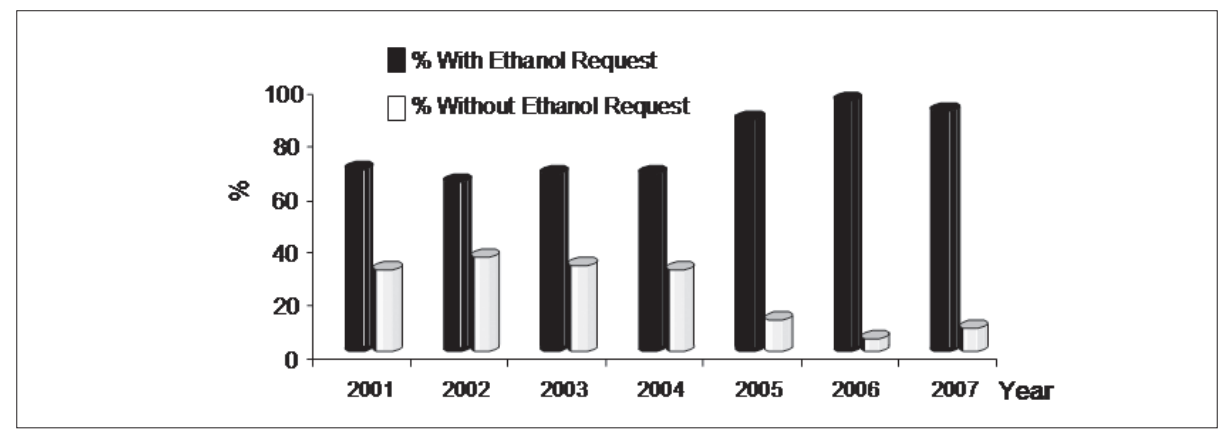

Figure 7 - Number of Traffic Accidents without Ethanol request (in the Legal Medicine Office of Figueira da Foz).

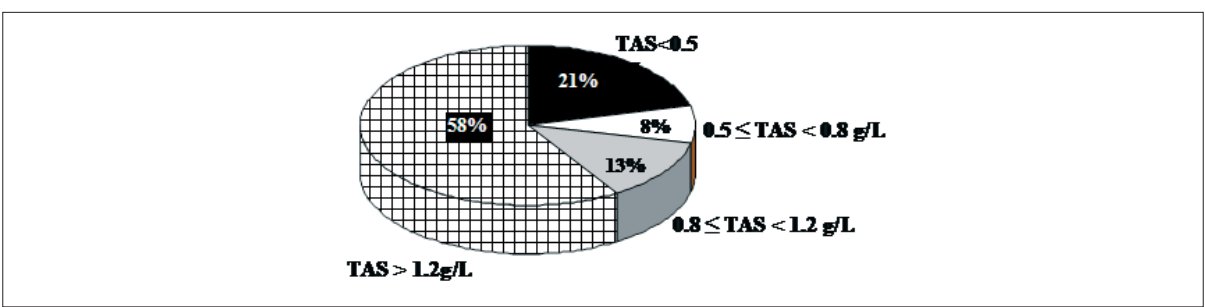

Figure 8 - Positive Ethanol Results distribution (in the Legal Medicine Office of Figueira da Foz).

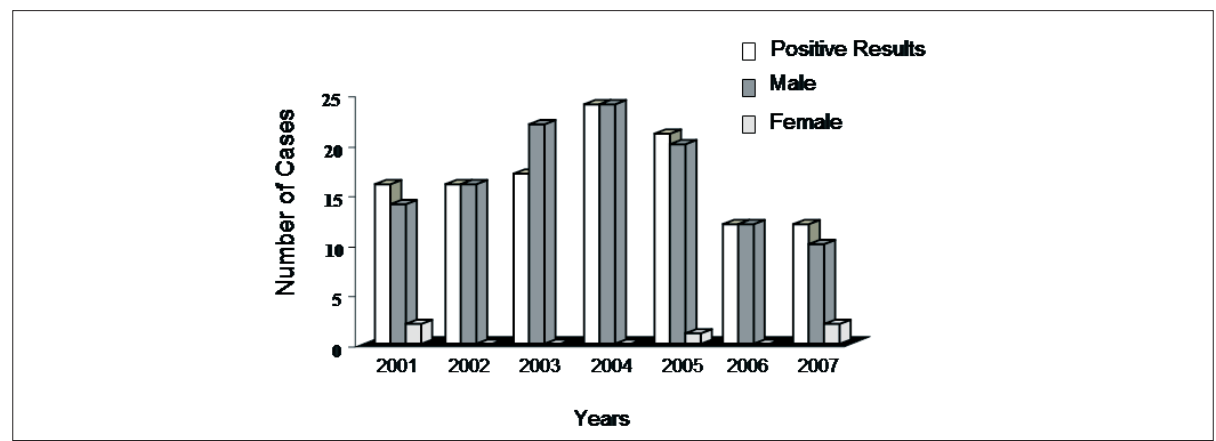

Figure 9 - Positive results distribution per gender/year (in the Legal Medicine Office of Figueira da Foz).

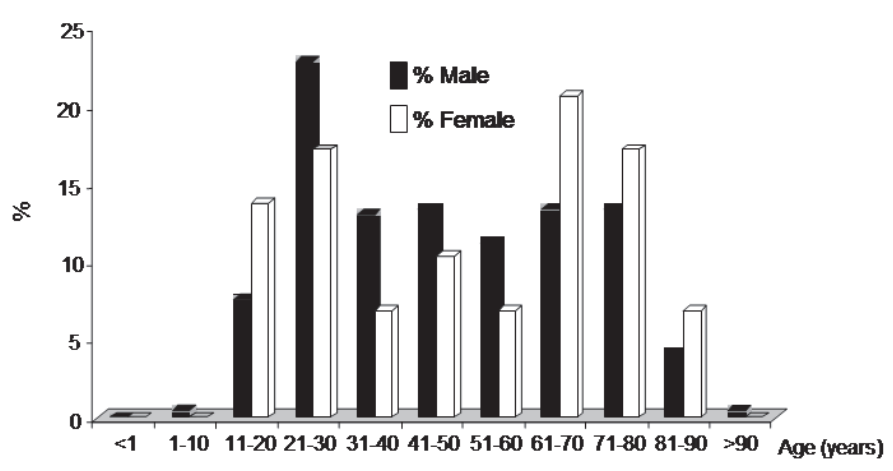

Figure 10 - Positive results distribution per gender/age (in the Legal Medicine Office of Figueira da Foz). 